Teologia i Moralność, volumen 12(2017), numer 1(21)

doi: 10.14746/tim.2017.21.1.3

JERZY GOCKO

Katolicki Uniwersytet Lubelski Jana Pawła II

Wydział Teologii

\title{
Istotne aspekty teologii migracji
}

Migracje towarzyszą ludzkości od zarania dziejów. Jednak szczególne ich nasilenie widoczne jest w czasach obecnych. Współczesne ruchy migracyjne przybierają bardzo różne, często skrajnie odmienne formy, przede wszystkim dlatego, że różnorodne bywają ich przyczyny. Inna jest bowiem mobilność wynikająca ze swobodnie dokonanego przez osoby zainteresowane wyboru, inna zaś ta, która rodzi się ze wszelkiego rodzaju przymusu: ideologicznego, politycznego, ekonomicznego lub jakiegokolwiek innego.

Mobilność społeczna jest przyczyną i zarazem owocem ery postindustrialnej i należy ją odczytywać jako współczesny ,znak czasu”. Można zaryzykować stwierdzenie, że właściwie cała rzeczywistość przybrała charakter ponadlokalny, stając się właściwie rzeczywistością globalną: ekonomia dzięki natężeniu procesów globalizacyjnych zyskała wymiar ponadnarodowy i ponadregionalny, polityka - by stać się realistyczną - nabiera wymiarów światowych; również ośrodki życia społecznego mają zasięg ogólnoświatowy ${ }^{1}$. Rozpoczynając więc próbę określenia elementów teologii migracji, co przypomina układanie mozaiki, za podstawowy punkt wyjścia należy przyjąć nie tyle samo zjawisko mobilności, ile raczej kierunek ewolucji świata jako całości. Świat obecny charakteryzuje się wzajemnym przenikaniem cywilizacji, kultur i ideologii. Stał się mały, nazywa się go globalną wioską, w której granice stopniowo znikają, a wydarzenia odbijają się echem nawet w najbardziej odległych obszarach ${ }^{2}$.

${ }^{1}$ Por. S. Castles, M.J. Miller, Migracje we wspótczesnym świecie, thum. A. Gąsior-Niemiec, Warszawa 2011, s. 19-24.

${ }^{2}$ Por. Papieska Komisja do spraw Duszpasterstwa i Turystyki, Wstęp, w: tenże, Kościół a ruch migracyjny, Watykan 1978. 


\section{Fenomen migracji}

Migracje z punktu widzenia historycznego należały, należą i zapewne będą należeć do najzwyklejszych zjawisk życia społecznego ${ }^{3}$. W większości teologicznych opracowań encyklopedycznych artykuły poświęcone migracji rozpoczynają się stwierdzeniem, że pierwsza migracja odnotowana w Biblii miała miejsce podczas wymieszania języków (por. Rdz 11,8), w następstwie czego ludzkość została rozproszona po całej Ziemi. Jak informuje Księga Rodzaju, miejsce to nazwano „Babel, tam bowiem Pan pomieszał mowę mieszkańców całej ziemi. Stamtąd też Pan rozproszył ich po całej powierzchni ziemi" $(\operatorname{Rdz} 11,9)$.

Warto przywołać to biblijne zdarzenie nie po to, aby uzasadnić nim nierozdzielność ludzkiego losu od zjawiska migracji, ale z powodu jego symbolicznego i ważnego dla teologicznomoralnych rozważań znaczenia. Odniesienie migracji do budowy wieży Babel sytuuje ludzką migrację w negatywnej perspektywie, która zaciąży na dalszych dziejach człowieka. Nie oznacza to, że migracja w bezpośredni sposób jest następstwem grzechu, ale $\mathrm{z}$ drugiej strony trudno nie dostrzec jej związku z grzeszną kondycją człowieka, z niesprawiedliwością, ze złem, nawet jeśli inne znaczące biblijne obrazy migracji ludów opisują ją wprost jako element historii zbawienia. Należy tu wspomnieć przede wszystkim exodus z Egiptu i eschatologiczny odpowiednik wygnania spod wieży Babel, czyli opisaną w Apokalipsie eschatologiczną wędrówkę ludów ku Nowemu Jeruzalem na końcu czasów.

W tej perspektywie jeden z głównych dokumentów Magisterium o migracji Instrukcja Erga migrantes caritas Christi ${ }^{4}$ stwierdza: „Dla Kościoła dzieje migrantów są prowokacją wiary i miłości wierzących, zachęcanych w ten sposób do uzdrowienia zła wynikającego z migracji i do odkrycia planu, jaki Bóg urzeczywistnia w nich nawet wtedy, gdy są powodowane oczywistą niesprawiedliwością" (nr 12).

Tak więc - patrząc na migracje - ma się do czynienia z jednej strony z normalnym faktem czy zjawiskiem społecznym, które $\mathrm{z}$ drugiej strony naznaczone jest określoną antropologiczną nienormalnością, co rodzi etyczne/moralne konsekwencje; staje się - używając kategorii teologicznomoralnych - wyzwaniem, domaga się określonych norm, cnót, postaw i działań.

Owa antropologiczna nienormalność jest łatwa do wyobrażenia, gdy uwzględni się sytuację i warunki życia migrantów. Są one najczęściej przeciwieństwem tego wszystkiego, czego do normalnego życia potrze-

${ }^{3}$ Cytaty biblijne z Biblii Tysiąclecia, Poznań $2003^{5}$.

4 Papieska Rada ds. Duszpasterstwa Migrantów i Podróżnych, Instrukcja na temat zjawiska współczesnej migracji Erga migrantes caritas Christi, „Acta Apostolicae Sedis” 96(2004), s. 762 -822 (tekst polski: Lublin 2009). 
buje człowiek. I nie jest to zjawisko nowe, związane z obecnym problemem uchodźców. Towarzyszyło ono migracji zawsze, nawet jeśli nie było definiowane w kategorii godności czy praw człowieka, co ma miejsce obecnie.

Samo zjawisko migracji we współczesnym świecie przechodzi poważną ewolucję. Zmianom ulegają jego uwarunkowania, charakter i kierunki. Obok regionalnych przepływów nasiliły się migracje kontynentalne oraz interkontynentalne. Oprócz wojen i konfliktów, które od zarania ludzkości były główną ich przyczyną, obecnie zasadniczą rolę w kształtowaniu się migracyjnego potencjału i w jego wzroście odgrywają - z jednej strony - zjawiska ludnościowe (eksplozje demograficzne w wielu krajach - Indiach, Pakistanie, krajach afrykańskich), a także utrzymujące się i rozszerzające się bezrobocie; z drugiej strony - głębokie zmiany w ekonomice światowej, powstanie i rozwój prężnych ośrodków gospodarczych i nowoczesnych branż wytwórczości, wielostronny rozwój sfery usług. Procesom migracyjnym sprzyjają i je ułatwiają: postęp w transporcie, rozwój motoryzacji i komunikacji lotniczej, a także nowoczesne systemy mediów, przekazu, łączności i technologii informatycznej ${ }^{5}$.

\section{Perspektywa biblijna}

Prezentację istotnych elementów „teologii migracji” - jak już nadmieniono - warto obrazowo porównać do układania mozaiki, która dopiero w całości może stać się normatywnym fundamentem dla chrześcijańskiej etyki migracji. Elementy do mozaiki czerpać należy przede wszystkim z Pisma Świętego, Tradycji, dorobku myśli teologicznej, Magisterium Kościoła, katolickiej myśli społecznej czy z wkładu personalizmu chrześcijańskiego. Każde z tych źródeł wnosi nowe aspekty.

Uprzedzając dalsze rozważania, już w tym miejscu trzeba wskazać na pewną zmianę w rozłożeniu akcentów. Wiąże się ona z odchodzeniem od partykularnych sposobów argumentacji, odwołujących się do doświadczeń określonej społeczności religijnej (ludu Starego Przymierza, potem Kościoła) i systemów moralnych z nimi związanych, do argumentacji o charakterze w coraz większym stopniu uniwersalnych. Takie elementy pojawiały się stopniowo (np. w podkreśleniu znaczenia miłości braterskiej, w nowym spojrzeniu na innego/ /obcego, w argumentacji uzasadniającej prawo do migracji na podstawie zasady społecznej wypracowanej na kanwie nauczania społecznego Kościoła dotyczącej powszechnego przeznaczenia dóbr ziemskich), by swoje apogeum znaleźć w etosie praw człowieka. Nauczanie Kościoła w najnowszych doku-

5 Por. Causes and Consequences of Human Migration: An Evolutionary Perspective, ed. M.H. Crawford, B.C. Campbell, New York 2012. 
mentach uczyniło je swoim, nie pomniejszając tego wszystkiego, co wynikało $\mathrm{z}$ dotychczasowych interpretacji.

Punktem wyjścia wszelkiej teologii, a więc także teologii migracji, jest perspektywa biblijna. Ta - w odniesieniu do migracji - jest bardzo bogata zarówno w Starym, jak i Nowym Testamencie. Już u zarania dziejów ludu Bożego znajduje się wezwanie do emigracji: „Wyjdź z twojej ziemi rodzinnej i z domu twego ojca do kraju, który ci ukażę" (Rdz 12,1). Abraham opuszcza własny dom, swoich najbliższych, swoje środowisko rodzinne $\mathrm{i}$ - pełen wiary i nadziei - podejmuje podróż w nieznane. Jego emigracja nie jest jedynie jakimś zaprzeszłym wydarzeniem, lecz staje się w Starym Testamencie znakiem wyróżniającym lud Boży, wezwany do opuszczenia dotychczasowej ojczyzny i wyruszenia w kierunku nowego nieba i nowej ziemi.

Abraham jest bez wątpienia także postacią typiczną dla przybysza/cudzoziemca/obcego. Kiedy - po śmieci Sary - zwraca się do Chetytów, chcąc nabyć grób dla żony, przedstawia się jako przybysz: „Choć mieszkam wśród was jako przybysz, sprzedajcie mi tu u was grób na własność, abym mógł pochować moją zmarłą (żonę)" (Rdz 23,4). Biblia hebrajska na określenie przybysza używa terminu ger wetosab, co - wiernie tłumacząc - oznacza 'obcy i tymczasowo zamieszkujący'.

Określenia te, po raz pierwszy użyte w Piśmie Świętym, doskonale oddają status społeczny i psychologiczny migranta, który opuścił swój dom i udał się $\mathrm{w}$ nowe miejsce. Septuaginta thumaczy terminy te jako paroikos kai parepidemos. W obu tych słowach odpowiednio zawarta jest idea domu/rodziny (oikos) i ludu/narodu (demos). Przedrostki para- i epi- nadają następującym po nich terminom albo znaczenie przeciwne albo pozorne ${ }^{6}$. Przybyszem (używając thumaczenia z Biblii Tysiąclecia) jest więc imigrant, który z różnych względów musi pozostawić swój dom/ojczyznę i który usiłuje zbudować relacje solidarności w nowym domu/narodzie/ojczyźnie.

Inny przykład ludu w drodze, który - mimo że otoczony przez różne bezbożne narody - w swej istocie dochowa wierności, ukazuje Księga Wyjścia. Chodzi, oczywiście, o wyjście z niewoli egipskiej i zajęcie ziemi Kanaan. Wielkie znaczenie w tym przypadku ma to, że bycie obcym/uchodźcą/ /emigrantem stało się częścią tożsamości ludu Izraela, i to w podwójnym rozumieniu, poniekąd wzajemnie wykluczającym się. $Z$ jednej strony Izrael ma pielęgnować wspomnienie bycia cudzoziemcem, (co zostało silnie osadzone w zwyczajach i kulcie narodu, np. w celebrowaniu co roku Paschy czy w wielu przypisach prawa bardzo życzliwego zwłaszcza w stosunku do cudzoziem-

${ }^{6}$ Por. B.H. Dunning, Aliens and Sojourners: Self as Other in Early Christianity, Philadelphia 2009, s. 47-49; Th.R. Schreiner, The new American Commentary, vol. 37: 1, 2 Peter, Jude, Nashville [USA Tennessee] 2003, s. 119. 
ców), z drugiej zaś strony ten sam Izrael ma czuć się przybyszem/obcym także w kraju, który posiadł jako swoją ojczyznę, Ziemię Obiecaną, otrzymaną w darze ${ }^{7}$.

Warto podkreślić, że do tej tensji nawiązuje sam Jezus. Według Ewangelii Janowej, Jezus-Słowo stało się ciałem i zamieszkało między nami (por. 1,14), ale swoi potraktowali Go jako obcego i Go nie przyjęli. Echo tych słów wybrzmiewa także w modlitwie arcykapłańskiej: „Oni nie są ze świata, jak i Ja nie jestem ze świata" (J 17,16). Prowadzi to do otwarcia nowych horyzontów w kierunku ludzkiej solidarności, ponieważ Syn Boży, jak ma to miejsce w scenie sądu ostatecznego, utożsamia się z ubogimi, odrzuconymi i obcymi (por. Mt 25,31-46).

W Biblii przybysz/cudzoziemiec/obcy był często zaliczany do kategorii ludzi słabych (podobnie jak wdowy czy sieroty). Działo się tak przede wszystkim z powodu warunków życia z dala od ojczyzny/domu, ale także dlatego, że nie mógł nabyć ziemi w Izraelu, co było dość częste także w świecie hellenistycznym. Nie miał on także żadnej ochrony w społecznym systemie patriarchalno-rodzinnym. Stąd był zdany tylko na wsparcie z zewnątrz. Dlatego w Izraelu to Bóg był tym, który stał po ich stronie.

Prawo Przymierza uzasadniało stary zakaz wykorzystywania przybyszów doświadczeniem niewoli egipskiej: „Nie będziesz uciskał cudzoziemców, gdyż znacie życie cudzoziemców, bo sami byliście cudzoziemcami w Egipcie" (Wj 23,9). Tak jak lud Izraela był obcy i wykorzystywany w Egipcie oraz tęsknił za godnym człowieka życiem w wolności, tak winien zapewnić obcym przebywającym w jego kraju prawo do wolności i życia. To nakazywała także złota reguła (por. Tb 4,15; Mt 7,12).

Wymóg sprawiedliwości wobec różnych kategorii osób bezbronnych pojawiał się również w nauczaniu proroków. Na pierwszym miejscu spośród nich prorok Jeremiasz wymienia cudzoziemców. Prorok Ezechiel, z kolei, wśród złych czynów, które doprowadziły w 587 roku do upadku Jerozolimy, wylicza nieprawości, jakich doświadczyli cudzoziemcy. Analogiczne wymogi moralne dotyczące sposobu odnoszenia się do osób społecznie pokrzywdzonych, w tym cudzoziemców, pojawiają się także w nauczaniu Izajasza i Zachariasza ${ }^{8}$.

Pomijając $w$ tym miejscu szersze rozważania dotyczące troski o los cudzoziemców zawarte w Biblii, trzeba raz jeszcze podkreślić, że genezę ma ona we wspomnieniu własnych dziejów, w doświadczeniu bycia cudzoziemcem w ob-

7 Por. R. Urbańczyk, Moralno-spoleczne aspekty migracji w świetle nauczania Kościoła, Zabrze 2009, s. 54-55.

${ }^{8}$ Tematykę tę szeroko omawia A.S. Jasiński, Obcy w Starym Testamencie, w: Haurietis de fontibus. Społeczno-etyczne kwestie wczoraj i dziś. Księga pamiątkowa dedykowana ks. Doktorowi Piotrowi Kosmolowi, wykładowcy Wydziału Teologicznego Uniwersytetu Opolskiego, z okazji 40-lecia pracy dydaktycznej, red. P. Morciniec, Opole 2005, s. 40-45. 
cym kraju, a także pamięci o wyzwoleniu przez Tego, który „strzeże przybyszów" (Ps 146,9).

\section{Wezwanie do miłości roztropnej}

Warto jeszcze w tym miejscu wspomnieć, że ten obecny w całym Starym Testamencie nakaz przyjęcia przybyszów był podtrzymywany mimo wielkich obaw o utratę religijnej czystości i tożsamości religijnej. Zresztą, w hebrajskim tekście Starego Testamentu oprócz terminu ger, pojawiają się jeszcze dwa inne na określenie obcego: nokri i zar. W polskich tłumaczeniach są one przekładane na nieróżnicujący termin 'obcy' czy biblijny termin 'przybysz', gdy tymczasem przyjmują one odmienne znaczenie i tym samym odnoszą się do różnego kręgu osób. Nokri to ten, który uprzednio nie należał do ludu Izraela, ale przybył z ,własnego kraju”. Zar stał się określeniem technicznym dla pogan. Określani są nim także bezimienni prześladowcy, o których mówią psalmy (np. 54; 144,7.11). Na pewno zar nie byli zaliczani do tych obcych/ /przybyszów, wobec których postulowany był nakaz otwartości i gościnności ${ }^{9}$. Postawa ta jest odległa od jakiegoś bezrefleksyjnego przyjmowania do domu i wspierania obcych i przewrotnych ludzi.

Mądrość Syracha w tym kontekście przestrzega:

Nie wprowadzaj do domu swego każdego człowieka, różnorodne są bowiem podstępy oszusta $(11,29)$

lub w innym miejscu

Przyjmij obcego do domu, a wtrąci cię w zamieszanie i oddali cię od twoich najbliższych $(11,34)$.

albo

Jeśli chcesz dobrze czynić,

zważ, komu masz czynić [...] (Syr 12,1).

Szczegółowo zagadnienie to omawia ordo caritatis, które jest przedmiotem osobnego studium na łamach bieżącego tomu czasopisma „Teologia i Moralność". Warto tylko zwrócić uwagę na pojawiające się napięcie między przepi-

9 Por. A.P. Rethmann, Asyl und Migration. Ethik für eine neue Politik in Deutschland, Münster 1996, s. 240-241. 
sami prawa, zwłaszcza wywodzącymi się z tradycji Przymierza, nakazującymi dobre traktowanie przybyszów, a postawą ostrożności wobec obcych, a nawet niechęci do nich. Uwarunkowana ona była sytuacją geopolityczną i dziejami Izraela. Wydaje się, że z czasem zjawisko to jeszcze bardziej się pogłębiło.

\section{Miłość Chrystusa względem obcych i migrantów}

Teksty nowotestamentalne dotyczące migracji są świadectwem tego, że Kościół jako wspólnota uczniów Chrystusa odkrywał zawsze w migrantach oblicze samego Chrystusa, który był obcym i przychodniem (por. Mt 25,35), w Maryi zaś dostrzegał ikonę kobiety wędrującej ${ }^{10}$. W konsekwencji jego zaangażowanie na rzecz migrantów ,można przyrównać do miłości i współczucia Jezusa, Dobrego Samarytanina"11.

Widoczna od zarania dziejów Kościoła szczególna troska o migrantów wynika także z tak, a nie inaczej rozumianej tożsamości Kościoła, która wprost wskazuje na Kościół w drodze, na wspólnotę pielgrzymującą. W nawiązaniu do biblijnej teologii wyjścia Sobór Watykański II skonstatował, że „wspólnota (uczniów Chrystusa) składa się [...] z ludzi, którzy pielgrzymują do królestwa Ojca zjednoczeni w Chrystusie, kierowani przez Ducha Świętego, i którzy przyjęli orędzie zbawienia"12. Kościół jest niejako zawieszony w tensji eschatologicznej, między pierwszym przyjściem Chrystusa a ostatecznym spełnieniem, między già a non ancora ${ }^{13}$. Chrześcijanie nie mają tu na ziemi trwałego miasta, ale szukają tego, które ma przyjść (por. Hbr 13,14).

Pielgrzymowanie jest cechą wyróżniającą Kościół także w wymiarze instytucjonalnym i wynika z jego uniwersalizmu. Od początku towarzyszyło jego działalności misyjnej, łączyło się z ucieczką przed prześladowaniami czy znalazło wyraz także $\mathrm{w}$ różnych formach pobożności pielgrzymkowej. Tak tę tożsamość opisywał u zarania Kościoła autor listu do Diogneta: „Mieszkają

${ }^{10}$ Por. Papieska Rada ds. Duszpasterstwa Migrantów i Podróżnych, Instrukcja na temat zjawiska współczesnej migracji Erga migrantes caritas Christi, dz. cyt., nr 15; A.P. Rethmann, Asyl und Migration, s. 237-293.

11 A.M. Vegliò, R. Sarah, Prezentacja dokumentu, w: Papieska Rada ds. Duszpasterstwa Migrantów i Podróżujących, Papieska Rada Cor Unum, Przyjęcie Chrystusa w uchodźcach i przymusowo przesiedlonych. Wytyczne duszpasterskie, Watykan 2013, s. 3.

${ }^{12}$ Sobór Watykański II, Konstytucja duszpasterska o Kościele w świecie współczesnym Gaudium et spes, w: Sobór Watykański II, Konstytucje. Dekrety. Deklaracje, Tekst polski - nowe tlumaczenie, Poznań 2002, nr 1.

${ }^{13}$ Por. K.W. Merks, Migration als ethische Aufgabe. Zu den Möglichkeiten menschlicher Verantwortung angesichts komplexer Probleme, w: Migration und Menschenwürde. 23. Internationaler Kongreß der deutschsprachigen Moraltheologen und Sozialethiker 1987 in Passau, Hrsg. K.H. Kleber, Passau 1988, s. 45-55. 
każdy we własnej ojczyźnie, lecz niby obcy przybysze. Podejmują wszystkie obowiązki jak obywatele i znoszą wszystkie ciężary jak cudzoziemcy. Każda ziemia obca jest im ojczyzną i każda ojczyzna ziemią obcą. Przebywają na ziemi, lecz są obywatelami nieba"14.

To wszystko sprawia, że jednym ze znaków rozpoznawczych dla uczniów Jezusa stała się gościnność wobec podróżujących, a przybysze zawsze byli wyzwaniem dla wspólnot chrześcijańskich. $Z$ czasem dojdzie wypracowane i przyjęte prawo azylu. Wyjście i pomoc wobec migrantów były praktycznym wyrazem miłości bliźniego. W encyklice Caritas in veritate ${ }^{15}$ papież Benedykt XVI, wobec nabrzmiałych problemów współczesnego świata, przypomina, że nadal „miłość (caritas) jest fundamentem nauki społecznej Kościoła” (nr 2). Będąc nadprzyrodzonym darem, dalej może stać się „zasadniczą siłą napędową prawdziwego rozwoju każdego człowieka i całej ludzkości” (nr 1).

\section{Migracje w kontekście zasad życia społecznego}

Imperatyw zaangażowania na rzecz migrantów współczesne nauczanie Kościoła wyjaśnia także przez ,nierozerwalny związek między miłością Boga i miłością bliźniego"16. Papież Benedykt XVI zdecydowanie napominał, że „stwierdzenie o miłości Boga staje się kłamstwem, jeżeli człowiek zamyka się na bliźniego czy wręcz go nienawidzi [...]. Miłość bliźniego jest drogą do spotkania również Boga, a zamykanie oczu na bliźniego czyni człowieka ślepym również na Boga"17. Papież Franciszek w tym kontekście dodał: „Objawienie biblijne zachęca do przyjęcia obcokrajowca, zapewniając, że tak czyniąc, otwiera się drzwi Bogu, a w obliczu drugiej osoby dostrzega się rysy twarzy Jezusa Chrystusa" 18 .

Zaangażowanie na rzecz przybyszów wynika także z postawy solidarności, która jest „poczuciem wspólnej przynależności podyktowanej świadomością, że wszyscy tworzymy jedną rodzinę ludzką i jesteśmy od siebie zależni" "19. To solidarność każe opowiedzieć się po stronie biednych i bezsilnych. Solidarność musi jednak dotyczyć także przybywających, „którzy muszą przejawiać

${ }^{14}$ List do Diogneta, nr 5, w: Liturgia godzin, t. 2, Poznań 1984, s. 658.

15 Benedykt XVI, Encyklika Caritas in veritate, Watykan 2009.

${ }_{16}$ Benedykt XVI, Encyklika Deus Caritas est o miłości chrześcijańskiej, Watykan 2005, nr 16.

17 Tamże.

18 Orędzie Papieża Franciszka na Światowy Dzień Migranta i Uchodźcy 17 stycznia 2016 r. „Migranci i uchodźcy sa dla nas wyzwaniem. Odpowiedź daje Ewangelia mitosierdzia”. „L'Osservatore Romano" 36:2015 nr 10, s. 10-12.

19 Papieska Rada ds. Duszpasterstwa Migrantów i Podróżujących, Papieska Rada Cor Unum, Przyjęcie Chrystusa w uchodźcach, dz. cyt., nr 28. 
pełne szacunku zachowanie i otwarcie na kraj, który ich przyjmuje i wiernie przestrzegać jego praw" ${ }^{20}$.

Pomoc udzielana migrantom jest również wyrazem sprawiedliwości. To oczywiście podprowadza niniejszą refleksję do dominującego współcześnie nurtu argumentacyjnego, a więc kategorii godności każdego człowieka i przysługującego mu prawa do emigracji jako prawa człowieka. W 2001 roku na posiedzeniu Międzynarodowej Katolickiej Komisji ds. Migracji Jan Paweł II stwierdził: „Chciałbym was zaprosić do pogłębienia świadomości Waszej misji: [...] głosić i bronić godności każdego migranta, każdego przesiedleńca i każdego uchodźcy. W ten sposób pomoc, którą otrzymają, nie będzie uważana za jałmużnę wypływającą z dobroci serca, ale jako akt sprawiedliwości względem nich"21. Akt sprawiedliwości, czyli ten, który się należy z uwagi na uprawnienia drugiego człowieka i jego godność.

Tutaj tok argumentacji współczesnych dokumentów społecznych jest następujący: pod wpływem przekonania, że wszyscy ludzie są stworzeni na obraz Boży (argument teologiczny) i że człowiek jest przyczyną i celem całego życia społecznego (argument personalistyczny), Kościół uznał za konieczne bronić godności każdej osoby ludzkiej. Na jej mocy każdy ma prawo do życia, do nienaruszalności ciała, do posiadania środków potrzebnych do zapewnienia sobie odpowiedniego poziomu życia ${ }^{22}$. Jeśli prawa te we własnym kraju nie mogą być zagwarantowane, to w określonych okolicznościach dana osoba ma prawo udać się gdzie indziej, ponieważ ma właściwą sobie godność, która nie może być zagrożona. Widać więc, że prawo człowieka do migracji jawi się jako szczegółowa aplikacja bardziej pierwotnego prawa do tego, aby osiągnąć życie godne człowieka.

Naczelną normą etyczną przy ocenie zjawiska migracji jest rozwój i obrona praw osoby ludzkiej, a więc norma personalistyczna, co odpowiada podkreślanemu od Soboru Watykańskiego II we wszystkich dokumentach społecznego nauczania Kościoła personalistycznemu charakterowi życia społecznego. Punktem centralnym jest tu godność osoby ludzkiej, a więc zasadnicza równość wszystkich ludzi, bez żadnej dyskryminacji. Stąd wypływają podstawowe prawa, powszechne i niezbywalne.

Warto w tym miejscu zauważyć, że nauczanie Kościoła w tym aspekcie idzie dalej niż Powszechna Deklaracja Praw Człowieka, która stwierdza w artykule 13 (pkt. 2): „Każdy człowiek ma prawo opuścić jakikolwiek kraj,

20 Tamże, nr 29; Papieska Rada Cor Unum, Papieska Rada ds. Duszpasterstwa Migrantów i Podróżujących, Problem uchodźców, wyzwanie dla solidarności, Watykan 1992, nr 26.

21 Jan Paweł II, Przemówienie do uczestników Zgromadzenia Międzynarodowej Katolickiej Komisji ds. Migracji (12 listopad 2001) nr 2-3, „L'Osservatore Romano” (wyd. ang.), 2001, nr 47, s. 10.

22 Por. Jan XXIII, Encyklika Pacem in terris, Watykan 1961, nr 11. 
włączając w to swój własny, i powrócić do swego kraju". Jan Paweł II w encyklice Laborem exercens przypomina, że Kościół potwierdza i broni prawa człowieka do migracji, rozumiejąc je w dwóch podstawowych wymiarach: jako prawo do emigracji (prawo wyjścia z własnego kraju) oraz prawo do imigracji (prawo wejścia do drugiego kraju w poszukiwaniu lepszych warunków życia). Dla Kościoła zarówno prawo do emigracji, jak i prawo do imigracji są dwoma aspektami tego samego naturalnego prawa człowieka ${ }^{23}$.

Niezbędna wydaje się tu uwaga, że podstawowe i niejako nadrzędne względem prawa do emigracji jest prawo człowieka do życia we własnej ojczyźnie. Staje się ono jednak realne tylko wówczas, gdy nie występują czynniki zmuszające do opuszczenia jej. Realizacja tego prawa człowieka będzie się wiązała z równomiernym rozwojem gospodarczym, ze stopniowym eliminowaniem nierówności społecznych, a także z dobrym funkcjonowaniem struktur i procedur demokratycznych ${ }^{24}$.

W nawiązaniu do tej reguły wspomniana encyklika Laborem exercens dodaje, że ,jeśli nawet emigracja jest pewnym złem, jest to w określonych okolicznościach tzw. zło konieczne" 25 - sformułowanie na pewno bez precedensu w dokumentach społecznych Kościoła, a przez to niezwykle odważne. Jest w nim potwierdzenie prawdy, że nikt nie może zostać zmuszony do emigracji, czy to przez przemoc, czy konieczność szukania środków do przeżycia poprzez znalezienie odpowiedniego zatrudnienia. W takim bowiem przypadku emigracja jawi się jako zło konieczne. Także tu pozostaje jednak obowiązek moralny, ,uczynienia wszystkiego [...], ażeby zło w znaczeniu materialnym nie pociagnęło za sobą większych szkód w znaczeniu moralnym"26. Klucz do sukcesu tkwi więc w umiejętności i w chęci obrócenia tego zła w dobro.

Ojciec Święty wzmacnia dodatkowo tę koncepcję, wskazując, że w nowej sytuacji - „o ile to możliwe” - to tzw. zło konieczne powinno przynieść „nawet dobro w życiu osobistym, rodzinnym i społecznym emigranta”, i to zarówno „gdy chodzi o kraj, do którego przybywa, jak też o ojczyznę, którą opuszcza"27. Widoczne są więc wyraźnie trzy wymierne obszary możliwego do osiągnięcia dobra: człowiek jako podmiot emigracji, społeczeństwo, z którego on pochodzi, i społeczność, do której przybywa.

${ }^{23}$ Por. nr 23. Por. także: F.M. Schmölz, Migration und Menschenwürde, w: Migration und Menschenwürde, dz. cyt., s. 29-33.

${ }^{24}$ Por. E. Rusin, Migracja, w: Encyklopedia nauczania społecznego Jana Pawła II, red. A. Zwoliński, Radom 2005, s. 291.

25 Jan Paweł II, Encyklika Laborem exercens, Watykan 1981, nr 23.

26 Tamże.

27 Tamże. 
Katolicka teologia migracji nie zatrzymuje się jedynie na płaszczyźnie doktrynalnej, systematycznej. Rozwijana jest także na płaszczyźnie pastoralnej/duszpasterskiej. Taka jest bowiem specyfika posłannictwa Kościoła, który żadnej konkretnej sytuacji duszpasterskiej, w której przychodzi mu wypełniać własną misję, nie traktuje w kategoriach przypadku, ale jako sytuację przewidzianą przez opatrzność Bożą. Odpowiedzią Kościoła na migracje, zwłaszcza te nowożytne w XIX i XX wieku, było powołanie określonych struktur na różnych poziomach, w tym nie tylko Papieskiej Rady ds. Migrantów i Podróżujących, ale także różnych stowarzyszeń zakonnych z wyraźnie określonym charyzmatem posługi migrantom, oraz szereg dokumentów doktrynalnych. Trzeba tu wspomnieć również o wypracowanych różnych formach posługi pastoralnej nakierowanej na migrantów, i to zarówno w ramach duszpasterstwa zwyczajnego, jak i nadzwyczajnego. Wszystkie one wynikają - co warto raz jeszcze podkreślić - z woli Chrystusa wyrażonej w opisie sądu z uczynków miłości: „,byłem przybyszem, a przyjęliście mnie”.

\section{THE ESSENTIAL ASPECTS OF THEOLOGY OF MIGRATION}

\section{Summary}

The article presents the essential elements of the theology of migration. It resembles piecing together the jigsaw puzzle (mosaic), which when put together, can become the normative foundation for the Christian migration ethics. Most of all the elements for that mosaic can be taken from the Bible, the Tradition, the whole of achievements of theological thought, the Church Magisterium, the catholic social teaching and from the content of Christian personalism. Each one of these sources delivers new aspects.

Słowa kluczowe: migracje; teologia migracji; Kościół; zasady życia społecznego

Keywords: migration; theology of migration; the Church; the principles of social life

\section{BIBLIOGRAFIA}

Biblia Tysiąclecia, Poznań: Wydawnictwo Pallottinum $2003^{5}$.

Benedykt XVI, Encyklika Caritas in veritate, Watykan: Libreria Editrice Vaticana 2009.

Benedykt XVI, Encyklika Deus Caritas est o miłości chrześcijańskiej, Watykan: Libreria Editrice Vaticana 2005. 
Castles S., M.J. Miller, Migracje we współczesnym świecie, tłum. A. Gąsior-Niemiec, Warszawa: PWN 2011.

Causes and Consequences of Human Migration: An Evolutionary Perspective, ed. M.H. Crawford, B.C. Campbell, New York: Cambridge University Press 2012.

Dunning B.H., Aliens and Sojourners: Self as Other in Early Christianity, Philadelphia: University of Pennsylvania Press 2009.

Jan XXIII, Encyklika Pacem in terris, Watykan: Libreria Editrice Vaticana 1963.

Jan Paweł II, Encyklika Laborem exercens, Watykan: Libreria Editrice Vaticana 1981.

Jan Paweł II, Przemówienie do uczestników Zgromadzenia Międzynarodowej Katolickiej Komisji ds. Migracji (12 listopad 2001) nr 2-3, „L'Osservatore Romano” (wyd. ang.), 2001, nr 47, s. 10.

Jasiński A.S., Obcy w Starym Testamencie, w: Haurietis de fontibus. Spoleczno-etyczne kwestie wczoraj i dziś. Księga pamiątkowa dedykowana ks. Doktorowi Piotrowi Kosmolowi, wykładowcy Wydziału Teologicznego Uniwersytetu Opolskiego, z okazji 40-lecia pracy dydaktycznej, red. P. Morciniec, Opole: Redakcja Wydawnictw WT UO 2005, s. 39-52.

List do Diogeneta (nr 5-6), w: Liturgia godzin, t. 2, Poznań: Pallottinum 1984, s. 658-659.

Merks K.W., Migration als ethische Aufgabe. Zu den Möglichkeiten menschlicher Verantwortung angesichts komplexer Probleme, w: Migration und Menschenwürde. 23. Internationaler Kongreß der deutschsprachigen Moraltheologen und Sozialethiker 1987 in Passau, Hrsg. K.H. Kleber, Passau: Passavia Universitätsverlag 1988, s. 35-69.

Orędzie Papieża Franciszka na Światowy Dzień Migranta i Uchodźcy 17 stycznia 2016 r. „, Migranci i uchodźcy sa dla nas wyzwaniem. Odpowiedź daje Ewangelia miłosierdzia”, „L'Osservatore Romano" 36:2015 nr 10, s. 10-12.

Papieska Rada Cor Unum, Papieska Rada ds. Duszpasterstwa Migrantów i Podróżujących, Problem uchodźców, wyzwanie dla solidarności, Watykan: Libreria Editrice Vaticana 1992.

Papieska Komisja do spraw Duszpasterstwa i Turystyki, Kościół a ruch migracyjny, Watykan: Libreria Editrice Vaticana 1978.

Papieska Rada ds. Duszpasterstwa Migrantów i Podróżnych, Instrukcja na temat zjawiska współczesnej migracji Erga migrantes caritas Christi, „Acta Apostolicae Sedis” 96(2004), s. 762-822 (tekst polski: Lublin 2009).

Rethmann A.P., Asyl und Migration. Ethik für eine neue Politik in Deutschland, Münster: LIT 1996.

Rusin E., Migracja, w: Encyklopedia nauczania społecznego Jana Pawła II, red. A. Zwoliński, Radom 2005, s. 290-291.

Schmölz F.M., Migration und Menschenwürde, w: Migration und Menschenwürde. 23. Internationaler Kongreß der deutschsprachigen Moraltheologen und Sozialethiker 1987 in Passau, Hrsg. K.H. Kleber, Passau: Passavia Universitätsverlag 1988, s. 13-34.

Schreiner Th.R., The new American Commentary, vol. 37: 1, 2 Peter, Jude, Nashville [USA Tennessee]: B\&H Publisching Group 2003.

Sobór Watykański II, Konstytucja duszpasterska o Kościele w świecie współczesnym Gaudium et spes, w: Sobór Watykański II. Konstytucje. Dekrety. Deklaracje, tekst polski - nowe thumaczenie, Poznań: Pallottinum 2002, s. 526-606.

Urbańczyk R., Moralno-społeczne aspekty migracji w świetle nauczania Kościoła, Zabrze: Wydawnictwo Gaudi 2009.

Vegliò A.M., Sarah R., Prezentacja dokumentu, w: Papieska Rada ds. Duszpasterstwa Migrantów i Podróżujących, Papieska Rada Cor Unum, Przyjęcie Chrystusa w uchodźcach i przymusowo przesiedlonych. Wytyczne Duszpasterskie, Watykan: Libreria Editrice Vaticana 2013, s. 3-6.

JERzY Gocko - prof. dr hab., Katolicki Uniwersytet Lubelski Jana Pawła II. 